\title{
4 The Role of the Economic, Technological, and Demographic Environments
}

\section{THE MPORTANCE OF BAGAININGOWER}

This chapter examines how various forces in the environment influence labor relations in emerging countries. We focus in particular on how factors in the economic, technological, and demographic environments influence the bargaining power of both labor and management. In doing so we are moving downward in our three-tiered framework by examining how external environmental factors influence the functional level of labor relations.

Bargaining power is a central concept in labor relations because it is the key determinant of bargaining outcomes related to wages and other work conditions. The influence of power is most evident in settings where employees are represented by unions because unions exercise their power through the formal mechanism of negotiations. And where there are negotiations, as we will discuss, there is always the threat of strike action (or strike-like actions) whether or not strikes are legal. The legality of strikes varies across countries and often also across different types of employees and employment relationships. A union will be better able to gain a high wage and other favorable contract terms when it has relatively high bargaining power. Often something in the environment determines whether a union has a lot of bargaining power in one situation and little power in another. Thus, we start this chapter with a discussion of how the environment influences bargaining power and the bargaining process. The text will show how a low unemployment rate (an aspect of the economic environment), for example, strengthens workers' ability to hold out when they are on strike and thereby gives a union greater bargaining power. 
An examination of bargaining power in unionized settings will also clarify what factors determine wages and working conditions where employees are not represented by unions and even where the employment relationship is not formally structured. (As discussed in chapter 6, unstructured employment relationships exist in what are labeled informal employment systems.) Even in the absence of unions and collective negotiations, some types and sources of bargaining power exist.

\section{A CONCEPTUAL FRAMEWORK FOR ANALYZING THE ENVIRONMENT}

This book uses as a framework an extension of the model proposed by John Dunlop. Dunlop theorized that three main influences shape the labor relations environment: (1) the economic context, (2) the technological context, and (3) the locus of power in the larger society. ${ }^{1}$ This book also considers the influence of the demographic context. The underlying theme is that labor and management can influence the environment and that the environment also influences them.

The external environment both incentivizes and constrains labor and management in their efforts to meet their goals. Thus, it is important to consider how the environment shapes the power of both parties. The parties involved in the employment relationship also seek to mold their environment to better serve their needs. Thus, environmental influences are not entirely outside human control.

For example, in recent years many employers have created global supply chains that typically involve increased outsourcing of production and use labor in a variety of countries and regions. They do so in large part to take advantage of a more favorable economic environment (such as lower labor costs or greater availability of resources). Many firms also have expanded internationally by investing abroad, forming partnerships with suppliers, or entering other types of joint ventures. These firms have directly shaped the economic environment for their labor relations.

The ability of the parties involved to influence their environment is even more pronounced in the case of public policy because both labor and management work to influence the public policies that regulate their own behaviors. Thus, in the long run, the environment is to some extent influenced by the both parties involved in employment relationships. Only in the short run should the environment be viewed as external and relatively fixed. 


\section{BARGANING PONER DEFINED}

The environment is particularly influential through the effects it exerts on the bargaining power of labor and management. Three aspects of bargaining power come into play: the total power, the relative power, and the political power of both labor and management. Total power concerns the total profits that are available to labor and management. The greater the total power is, the more profit is available for labor and management to divide up. Both labor and management prefer situations with greater total power. Relative power has to do with the relative strength of labor and management; in other words, the ability of either side to gain a larger share of a given amount of profit. Here the interests of labor and management conflict. Political power concerns the ability of labor or management to influence government actions - either the public policies governments adopt that influence labor relations or the actions governments take as an employer.

\section{Determinants of the Total Power of Labor and Management}

The total power of management is heavily influenced by two factors-the degree of compctition the employer faces and the state of the economy. The degree of competition means the amount of competition the employer faces from both domestic and international competitors. Firms that face few competitors and thercby have market power earn greater profits and thus have more resources for labor and management to divide up. In the most concentrated industries, a firm can become a monopoly and earn monopoly profits. In this case the total power of labor and management is at its maximum and bargaining is made casier by the fact that both high wages and high profits can be funded from the firm's monopoly profits.

The state of the economy influences total power by affecting the level of demand (i.e., sales) and profits. The interests of labor and management with regard to total power are similar as both sides prefer less competition and a strong economy.

\section{Determinants of the Relative Bargaining Power of Labor and Management}

The relative bargaining power a union has is heavily influenced by the ability of the union and its members to withdraw their labor, usually (though not always) through a strike. Workers are more likely to win higher wages and other gains when they are willing and able to sustain a strike. Moreover, strikes are more likely to succeed if the cost of the strike to the employer is 
significant. Thus, the employer's relative bargaining power is heavily influenced by his or her ability to withstand a strike. The simplest measure of relative bargaining power is the amount of strike leverage each party holds.

Workers can also withdraw their labor through more informal actions, such as working to rule (following rules strictly rather than pursuing effective work practices), enacting a strategy called the "blue flu" (large-scale worker absenteeism), and other means of slowing production. The discussion that follows focuses on the effects of strikes that involve workers who fully withdraw their labor. However, many of the points raised carry over to less extreme forms of labor withdrawal.

How Strike Leverage Influences Relative Bargaining Power The relative degree to which workers and the employer are willing and able to sustain a strike is their strike leverage. To measure each party's strike leverage, one needs to know what costs a strike would impose on each party and what alternative income sources are available to each party to offset any income losses induced by a strike. The discussions of the environmental contexts that follow help us understand what determines strike leverage.

\section{THE ECONOMV CONYEXT}

Economic factors significantly influence both total and relative bargaining power. Economic factors can be separated into those that operate at the macrolevel (economy-wide) and those that operate at the microlevel (relevant only to a specific bargaining relationship).

\section{Microeconomic Influences on Total Bargaining Power}

Microeconomic factors influence the total bargaining power of a particular employer or union through the effects of competitive conditions on a firm. The greater the market power of a firm (i.e., the less competition it faces in the markets in which it competes) the greater will be its profits. With greater profits, there are more resources for the parties to divide based on their relative power. A firm's market power is affected by the degree of domestic and international competition it faces. With regard to total bargaining power, labor and management have common interests; both sides prefer that the firm have market power. (This is true if other factors are held constant, especially factors that affect the relative power of labor and management.) The existence of these potential common interests explains why unions sometimes join with the management of a firm to push for government regulations that enhance the market power of the firm. For example, frequently unions representing 


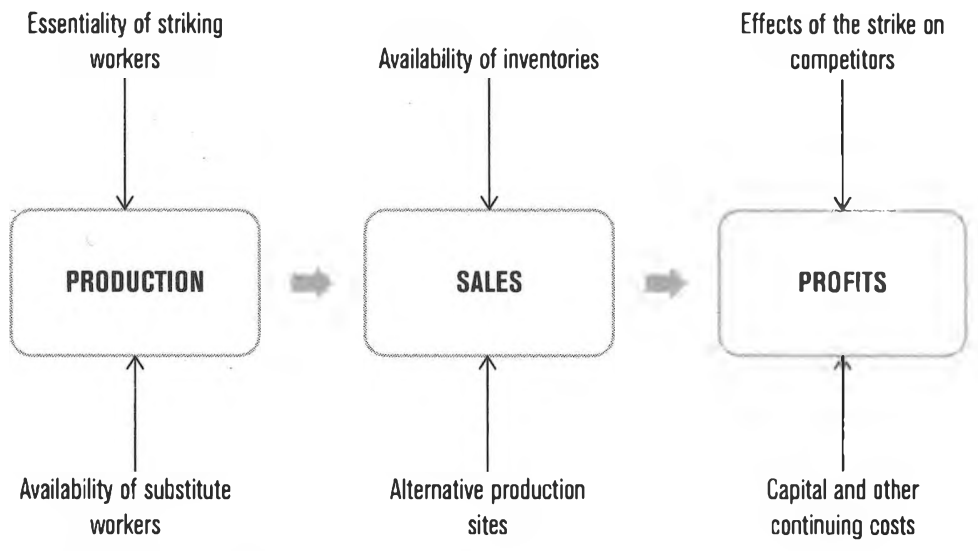

Figure 4.1. Determinants of managcment's strike leverage

steel workers join with steel companies to lobby their national government to restrict the importation of foreign steel and impose higher tariffs on those imports.

\section{Microeconomic Influences on Relative Bargaining Power}

Microeconomic factors influence the relative bargaining power of labor and management through effects on the strike leverage of the parties and the elasticity of demand for labor (the wage-employment trade-off).

Management's Strike Leverage The more an employer is willing and able to sustain a strike, the more likely the work force will be to settle a strike before achieving all of the union's goals. The strike leverage of employees derives from the strike's influence on firm profits. The greater the profits lost by the firm, the more ready the firm will be to give in to labor's demands. During a strike, a firm's profits are, in turn, shaped by the strike's effects on production and sales. Figure 4.1 diagrams the principal determinants of an employer's strike leverage. These include the ability to of workers to harm production, sales, and profits and the ability of management to find alternative means to maintain production, sales, and profits.

The effects of a strike on production: Once a strike has begun, the first indicator of workers' bargaining power is the degree to which the strike has impaired production and/or service. Workers who succeed in actually halting production because there are no readily available labor substitutes-supervisors, employees from another plant, strikebreakers, or automated equipmenthave substantial strike leverage and bargaining power. In other words, these 
workers are essential to the production process. Craft workers, who are typically very difficult to replace because of their skills, often have significant strike leverage. For example, the high skill levels of electricians and repair machinists help explain why they earn so much more than production workers in the auto, steel, and textile industries.

The effects of a strike on sales: The power of a striking work group is tempered, however, if the halt in production does not lead to a reduction in sales. Employers can sever or at least weaken the link between production and sales if inventories are high or if alternative production sites can be used to produce what normally would be produced at the site where the strike is taking place. Whether alternative production is available is influenced by the bargaining structure (whether other sites are covered by the same union or contract) and by the extent to which other workers at other sites join or support the strike.

The effects of a strike on profits: Even if production and sales are stopped by a strike, the firm may not necessarily experience a serious decline in profits. For example, firms with relatively low ongoing capital or interest expenses will have an easier time withstanding a loss of income caused by a strike. Also, firms facing a strike that also shuts down all the competitors' operations have an easier time withstanding a strike because sales and profits may be largely postponed rather than permanently lost. Firms that have substantial savings or alternative income sources (such as from other lines of business) can more easily absorb the costs of a strike. Later sections of this chapter discuss how the recent growth in employers' nonunion operations has improved their strike leverage through this channel.

The Union's Strike Leverage Consider the other side - the union's strike leverage. A union's strike leverage is determined by the ability and willingness of the work force to stay out on strike. The longer workers are willing and able to stay on strike, the greater the bargaining power the union has and the more likely it is to win favorable employment terms from an employer, other factors being constant.

Alternative sources of worker income: Workers' willingness to stay out on strike is heavily influenced by the degree to which alternative sources of income are available to them. Obviously, workers in unions that offer ample strike benefits can afford to stay out on strike longer than those in other unions. Likewise, when striking workers can more readily find temporary or part-time work that supplements union strike benefits or when they have substantial savings or assets, they are more able to sustain a strike action.

Worker solidarity: Another factor that influences workers' strike leverage beyond the microeconomic environment is the attitude of union members. 
Workers' feelings of solidarity with one another influence whether picket lines will be honored, and any pent-up frustrations will influence workers' willingness to stay out on strike. In brief, strikes are highly emotional undertakings and they depend on numerous factors, not simply the microeconomic environment.

\section{The Wage-Employment Trade-Off}

Strike leverage determines whether workers are able to press for a higher wage settlement or other contractual provisions. But higher wages often bring cuts in employment, and thus unions may in some cases choose not to raise wages as much as they could. This is called the wage-employment trade-off.

The key point is that wage increases can bring employment effects as well as direct wage gains. Unions sometimes moderate their wage demands because of employment cffects. For example, management often threatens unionized apparel workers with the claim that if they succeed at pushing wages significantly higher, the company will shift its production to other countries. In recognition of this threat, apparel unions in various countries have at times moderated their wage demands. This trade-off between wages and employment is thus another important microeconomic influence on bargaining power and outcomes.

Marshall's Four Basic Conditions and How Each Affects the Wage-Employment Trade-Off Unions are more likely to consider the employment effects that result from a wage increase when these effects are greater. Why a wage increase leads to large reductions in employment in one situation and to small reductions in another situation is explained by Marshall's conditions. In his seminal analysis of the relative bargaining power of labor and management, Alfred Marshall argued that unions are most powerful when the demand for labor is highly inelastic - that is, when increases in wages will not result in significant reductions in employment in the unionized sector. ${ }^{2}$ Marshall further proposed four basic conditions under which the demand for union labor would bc inelastic: (1) when labor cannot be easily replaced in the production process by other workers or machines; (2) when the demand for the final product is price inelastic (that is, demand is not sensitive to changes in the price of the product); (3) when the supply of nonlabor factors of production is price inelastic; and (4) when the ratio of labor costs to total costs is small. ${ }^{3}$ Below we address each of these conditions in turn.

The difficulty of replacing workers: The first condition, the degree to which workers are difficult to replace, depends on the production technology. The more 
difficult it is to replace workers with machines or other workers, the less apt the workers will be to fear that they will be displaced.

Unions can try to limit the ease with which management can introduce new technology by raising the cost of substituting other factors of production for union labor, but that strategy presents a dilemma. Collectively bargained constraints on technological change may keep unions from losing jobs, but slowing that rate of technological change may also constrain the rate of productivity growth, limiting the long-run potential for wage increases.

The demand for the product: Workers face less of an employment decline from raising wages if the demand for the product produced by these workers is not sensitive to the price of the product. This sensitivity (what economists call the elasticity of product demand) is a second key condition Marshall identified. This condition is somewhat different from the other three in that it is influenced by consumer preferences and not by the actions of the firm or the union. The elasticity of product demand depends on the willingness of consumers to substitute other products.

A modern-day illustration of this principle is the threat to union power raised by less expensive foreign imports that become more attractive to domestic consumers as wages and prices in the unionized domestic economy rise. The lower prices of goods produced in the auto, apparel, steel, and electrical appliance industries in many emerging countries have put pressure on producers in more industrialized countries and thereby illustrate this aspect of Marshall's conditions. Many unions try to influence consumer actions through "Buy Union" campaigns and counteract the pressure of lower priced goods.

The supply of other inputs: Marshall's third condition is the responsiveness of the price of other inputs in the production process to the demand for those inputs (what economists call the elasticity of supply of other factors of production). When an employer turns to alternative inputs such as machines or other factors of production in order to economize on the cost of labor, unions will be more able to push up wages (with less fear of employment cutbacks) if the price of those other inputs increases as their use increases. Thus, the more inelastic the supply curve for alternative inputs is, the greater is union power. Whereas Marshall's first condition concerns the degree to which it is technologically feasible to substitute other factors of production for unionized labor, his third condition concerns the costs to the firm of increasing its use of alternative factors.

Labor's share of total costs: Marshall's fourth condition is that unions are more powerful when labor costs represent only a small proportion of total costs. This condition has often been restated as "the importance of being unimportant." An employer is less likely to resist union pressure if a given wage 
increase affects only a very small proportion of the total cost of the product. Thus, a small craft unit, such as the skilled maintenance employees in a plant, is often less likely to meet management resistance to its wage demands than would a broad bargaining unit that represents all production and maintenance employees. ${ }^{4}$

Bargaining in the public sector illustrates the difficulties unions experience when labor costs represent a large proportion of total production costs. Labor costs for governments often run between 60 and 70 percent of the budget, and for some occupations such as firefighters these costs run as high as 90 percent of the budget. When government officials seek to control total budget costs, they take a very hard line in collective negotiations because the wages and salaries of public employees represent their largest controllable cost.

All of Marshall's conditions are based on the assumption that workers and unions are concerned about the employment effects of wage increases. If union members are willing to accept a slow rate of growth in employment or a decline in the number of union jobs as a trade-off for higher wages, the sources of power discussed above are less important. The extent to which unions factor in the wage-employment trade-off in their negotiations depends on factors such as the political dynamics in the respective union and whether or not macroeconomic conditions provide good alternatives in the labor market. If favorable labor market alternatives prevail (i.e., a low unemployment rate and strong economic growth), then workers and their union are likely to be less concerned with potential employment reductions that would follow wage increases in a particular negotiation.

\section{Macroeconomic Influences on Total and Relative Bargaining Power}

Economists refer to unemployment and the growth in national productivity as macroeconomic factors. The overall state of the economy affects bargaining power through a variety of channels. A firm is likely to be earning higher profits (greater total power) when the economy is strong and demand is growing.

A union's strike leverage depends in part on the availability of jobs, for both the striking workers and their spouses or other family members who might help support the strikers. The higher the unemployment rate, the less likely it is that striking workers or family members will be to find substitute employment and the more likely it is that other family wage earners will be out of work. Thus, unions generally gain strike leverage during the upswing of a business cycle, when the unemployment rate declines. Conversely, the relative power of unions declines during periods of rising unemployment. 
The factors at work here include those discussed earlier regarding striking workers' needs for alternative income sources and employers' vulnerability to strikes when product demand is high. During periods of slack demand employers may, in fact, welcome a strike because they can lower their inventories during the strike and use the strike as a substitute for layoffs.

\section{POLITICAL POWER}

The power of labor and management is influenced by their respective political power through a variety of channels. As mentioned above, one example of how politics matters is through the influence of public policies on the macroeconomic policies that affect the total and relative power of labor and management. Yet, as discussed in chapters 2 and 3, the legal system and a number of public policies significantly shape labor relations. So the political power of labor and management matters because that power influences the laws and public policies that regulate labor relations. In many emerging countries, public policies also directly affect government regulation of pay and social welfare policies, such as pensions, vacations, and health care. This provides another channel through which political power affects the bargaining power of labor and management. In addition, as will be discussed more fully in chapter 10, in emerging countries governments are often significant employers. Political power thus also influences employment terms and conditions through its effects on the role governments play as an employer.

\section{THE ECONOMIC ENVIRONMENT}

The power and influence that labor, management, governments, and other actors have in labor relations is shaped by the economic environment in which those parties operate. In the sections that follow in this chapter, we examine the key components of the economic environment in emerging countries, including the role of demographic factors such as population and urbanization trends, child labor, and educational attainment.

\section{Size and Quality of the Labor Force}

A key factor that will affect a country's labor relations system is the size of the work force. Economists point out that a larger work force can contribute to economic growth in the long run by increasing the supply of labor. At the same time, an increase in the supply of labor can lead to downward pressures on wages in the short run because it often takes time for the effects of an increase in the labor supply to produce economic growth and the increases in the demand for labor that lead to wage growth over the longer term. 
The supply of labor, which has both quantity and quality dimensions, is the key determinant of the size of the work force. The quantity of labor in the labor market is influenced by the size of the working population, by the extent of rural-to-urban migration (which is commonly linked to a shift away from farm work), and by the amount of child labor. The quality of labor is influenced by the educational attainment of the work force. We discuss each of these key components below and highlight several policy issues related to labor supply that have recently surfaced in emerging countries, such as the discrimination urban migrants face and the labor market difficulties college graduates face.

\section{Population Trends}

In many emerging countries, the rate of population growth is faster than in most advanced industrialized countries, and this has contributed to growth in the labor forces of those countries. More than three-quarters of the world's people now live in emerging countries

The average life span remains about twelve years greater in the advanced industrialized countries as compared to emerging countries, although this gap has been sharply reduced in recent decades. In 1950, life expectancy at birth for people in emerging countries averaged 35 to 40 years, compared with 62 to 65 years in advanced industrialized countries. However, average life expectancy has been increasing in many emerging countries. In East Asia and Latin America, for example, life expectancies are now an impressive 74 and 73 years, respectively.

Because of high birth rates, populations are relatively youthful in emerging countries. Children under the age of 15 constitute more than 30 percent of the total population of emerging countries, but this group constitutes just 17 percent of the total population in advanced industrialized countries. In fact, in at least ten emerging countries, children under the age of 15 constitute over 44 percent of the total population. As a result, the work force in emerging countries must support almost twice as many children as it does in advanced industrialized countries.

\section{Urbanization and Migration Trends}

Generally, the more economically advanced the country, measured by per capita income, the greater the share of population living in urban areas. While individual countries become more urbanized as they develop, it is also the case that today's poorest countries are far more urbanized than the advanced industrialized countries were when they were at a comparable level of development, and on average emerging countries are urbanizing at a faster rate than emerging countries did in the nast 
One of the most significant modern demographic phenomena is the rapid growth of cities in emerging countries. The most rapid urbanization is now occurring in Asia and Africa. It is forecast that before 2030, more than half of all people in these regions will live in urban areas. ${ }^{5}$

A key source of the significant urban population growth in emerging countries is large-scale rural-to-urban migration. This migration has led to high rates of unemployment, as rates of rural-to-urban migration in emerging countries have exceeded rates of urban job creation and have strained urban social services. Another problem caused by these high rates of migration is that a high proportion of well-educated young people make up the migrant population and this depletes the rural countryside of skilled workers.

Rural-to-Urban Migration in China In China, migration of former farm peasants into urban areas has greatly increased the size of the work force in industrial enterprises in urban areas in recent years. This sort of migration was highly restricted before market reforms were introduced in China in the 1980s. Under the hukou system, individuals were required to be registered with the local authority where they wcre born and lived. Rural residents were not allowed to move to urban areas for employment. Although this restriction has gradually been eased during the reform era, rural migrants continue to suffer severe discrimination when they seek employment, legal protections, or public benefits in an urban area (see box 4.1).

\section{BOX 4.1}

\section{The Hukou Registration System in China}

The number of Chinese workers moving from rural areas to large cities is large and increasing. In 2012, there were 262 million migrant workers in China (a 3.9 percent increase from 2011). Of these, 163 million had left their home province to work in other provinces.

When the Communist Party came to power in 1949, the government made restrictions on migration to urban areas to ensure that enough people were working in rural areas. In 1958, the government placed stricter control on internal migration of workers through a permanent registration process called the hukou system, a series of measures to prevent citizens seeking higher living standards from moving to cities without permission. 
Under the hukou system, the social benefits a person receives are tied to where he or she was born. The rigidity of the hukou system makes it nearly impossible for internal migrant families to reap the benefits of urban life. Without an official hukou (household registration record), a migrant worker's family is denied access to a range of city services, including medical care, pensions, government services, and education. The strict registration system deprives families of the supports they need to live. After the hukou system was made stricter in the 1950s, police began periodically enforcing the law by placing those who did not have legitimate registered permits in detention centers. Migrant workers without legal documentation were expelled from the city.

A large number of activist youths were relocated to rural areas during the Cultural Revolution of the 1960s and 1970s as punishment for their political activism. The government of China eventually permitted the young revolutionists to return to cities.

With the advent of increased technology it has been easier for police to enforce the hukou system using a national database of official hukou registrations. The denial of benefits to some migrant families in cities creates a major division between permanent residents and migrants. $\mathrm{Mi}-$ grant workers in cities are stigmatized and discriminated against. Migrant workers are restricted from access to public services, and they are often blamed for urban crime and unemployment.

Migrant workers also face discrimination from permanent residents who speak to them in public as if they are children. The workers are often banned from entering expensive restaurants and hotel lobbies. Adding to the discrimination, the Chinese word for these migrant workers, nongmin, refers an inferior educational and cultural status and inferior economic competencies.

In the last five years Chinese authorities have made some efforts to make it less difficult for migrant workers to move their hukou to the cities where they work. They are also trying to provide services in cities to all permanent residents. At the same time, the trend toward internal migration in China does not seem to be decelerating. Migrant workers now constitute about 20 percent of China's total population. It is expected that in the next several years, an additional 100 million more rural residents will migrate to cities.

Sources: National Bureau of Statistics of China, http://www.stats.gov.cn/ was40/gjtj_en_detail.jsp?searchword=migrants\&channelid $=9528 \&$ record $=3$; 
Bob Davis and Tom Orlik, "China Seeks to Give Migrants Perks of City Life," Wall Street Journal, March 5, 2013, http://online.wsj.com/article/SB10001424 $127887324178904578341801930539778 . \mathrm{html}$ cb=logged 0.3972573739010 8407; Hsiao-Hung Pai, "China's Rural Migrant Workers Deserve More Respect from the City Dwellers," The Guardian, August 25, 2012, http://www theguardian.com/commentisfree/2012/aug/25/china-rural-migrants-more -respect; PRI's The World, "China's Hukou System Puts Migrant Workers at Severe Economic Disadvantage," May 1, 2013, http://www.pri.org/stories/ politics-society/social-justice/china-s-hukou-system-puts-migrant-workers-at -severe-economic-disadvantage-13676.html; Wu Zhong, "How the Hukou System Distorts Reality," Asia Times, April 11, 2007, http://www.atimes. com/atimes/China/ID11Ad01.html.

The difficult economic and social conditions migrants face has emerged as a key public policy issue in a number of countries, not just in China. Box 4.2 highlights the problems migrants face in Singapore and the protests that are surfacing as migrants there seek improvements in their work lives and status.

\section{BOX 4.2}

\section{Frustrations Surface in the Ranks of Singapore's Migrant Workers}

Frustration among Singapore's unappreciated and underpaid migrant workers has been building in recent years as their numbers have grown faster than the country can accommodate them. Tensions boiled over earlier this month, after a 33-year-old Indian migrant worker was killed by a bus in the Little India neighborhood. A crowd of fellow workers from South Asia gathered at the scene. Their anger quickly escalated, with some 400 people pelting stones, attacking emergency responders and setting fire to vehicles. It was the worst riot to hit Singapore, one of the world's most orderly countries, since $1969 . .$.

Migrant laborers are paid as little as 2 Singapore dollars, or $\$ 1.60$, per hour. Few speak fluent English, the country's working language, and most live in crowded dormitories away from residential areas. They typically are at the mercy of employers, owe high debt to hiring agents and have few means of expressing grievances. Last year, 200 
Bangladeshi workers protested unpald wages and Chinese bus drivers nefused to report to work to protest salarles lower than their Singaporean and Malay counterpants.

Saure: Reprinted hom New Yok Times DAitorial Board, “Singapore's Angry Migrant Workers," New York TRues, December 27, 2013.

\section{Educational Attainment}

The education levels of workers are an important factor in labor relations. Educational systems vary from country to country. There are differences in the age when students typically begin and end each phase of schooling, the duration of courses taken, and what students are taught and expected to learn. These differences make it extremely complicated to draw international comparisons based on education. ${ }^{6}$

There have been dramatic improvements in education throughout the world. Today, 82 percent of all people are literate, compared to 63 percent as recently as 1970 . Since 1950 , there have been significant reductions in education inequality based on gender in emerging countries, although the need for further progress remains, as two-thirds of the world's illiterate people are women.

At the same time, education levels in emerging countries continue to seriously lag behind levels in advanced industrialized countries. For example, in Europe, North America, or Japan, children can expect to receive more than twelve years of schooling. The average child in sub-Saharan Africa and South Asia, in contrast, can expect to spend less than five years in school.

Since 1950, the average years of schooling among the total population 15 years and older in emerging countries has increased significantly, from 2.1 years to 7.1 years. In South Asia and the Middle East/North Africa regions, average years of schooling have more than doubled since the 1980s. The improvements in completion and enrollment ratios at all levels among the younger cohorts in every generation contribute to a continual increase in the average years of schooling as these cohorts mature over time. The biggest improvement in average years of schooling among the younger cohorts was recorded during the period 1970 and 1990 in both emerging and advanced industrialized countries.

The more rapid the rate of population growth, the greater the proportion of dependent children in the total population and the more difficult it is for people who are working to support those who are not. 
A key fact is that while emerging countries contain more than 80 percent of the world's population, they account for only half of the world's population that has attained some form of higher education. At the same time, improvements in education will not lead to sustained improvements in standards of living if there are not adequate jobs that require the higher skills of the better educated. Box 4.3 describes recent concerns about a potential oversupply of college-educated individuals in China. Similar concerns have appeared in other emerging countries recently.

\section{BOX 4.3}

\section{The Oversupply of College Graduates in China}

Prior to the 1990 s, only the top 4 percent of Chinese students were able to attend college and there were plenty of college graduate-level jobs to go around. However, in the past few decades, enrollment in public universities in China has increased rapidly, which has increased the number of students eligible for a college degree. The number of university graduates has nearly doubled since 2002. The percentage of college-age people attending university went from 4 percent to about 20 percent since 2002. However, this number still lags behind the comparable figures for advanced industrialized countries, where 40 percent or more of college-age students are enrolled in universities.

The oversupply of students first emerged in 1999, when Chinese authorities initiated policies to increase college enrollment in order to prepare young Chinese adults for a twenty-first-century economy. Although China's economy is growing rapidly, there are not enough jobs for the number of university graduates. The total number of graduates for the current decade is expected to reach 94 million, which is nearly double the graduate rate of the previous decade. Graduates are extremely disappointed in their quest to find quality work, make good money, and live a comfortable lifestyle.

As a result of the lack of jobs, some college graduates are seeking to leave China and work abroad. Pressures are building among graduates whose skills are not being fully utilized.

Source: Sophie Song, "Future of Chinese Graduates Is Bleak: More Than Half Will Have to Take Blue-Collar Jobs by 2020," International Business Times, June 10, 2013, http://www.ibtimes.com/future-chinese-college-graduates -bleak-more-half-will-have-take-blue-collar-jobs-2020-1298875. 
Gender Gaps in Education Young females receive less education than young males in most emerging countries. The gender gap in education is especially great in emerging countries in Africa, where female literacy rates can be less than half that of men. In most emerging countries, women make up a minority of college students.

There are several reasons why closing the educational gender gap by increasing the educational opportunities for women is economically desirable. First, the increase in earnings due to education is greater for women than it is for men in most emerging countries. Another reason why it is economically desirable to close the educational gender gap in emerging countries is that increasing women's education not only increases their productivity in the workplace, it also results in greater labor force participation, later marriage, lower fertility, and greatly improved child health and nutrition, thus benefiting the next generation as well. Further, because women carry a disproportionate burden of poverty, any significant improvements in their role and status through education can have an important impact on breaking the vicious circle of poverty and inadequate schooling. Studies also show that mothers' education plays a decisive role in raising levels of nutrition in rural areas.

In summary, while significant improvements have occurred in the level and spread of education in emerging countries in recent years, these countries still face great challenges as they seek to improve access to education.

\section{Child Labor}

Another critical aspect of the economic environment that has particularly large effects on labor relations in emerging countries is child labor. The volume of child labor matters in part because of the effects it has on increasing the supply of labor. In addition, child labor nearly always takes place under very poor work conditions that include low pay and unsafe work. Child laborers are not the only workers affected by these poor conditions; they spread and affect other workers at the low end of the labor market.

A comprehensive report on child labor published by the International Labour Organization in 2013 documents that 168 million children worldwide are laborers; this group accounts for almost 11 percent of the child population as a whole. ${ }^{7}$ Children in hazardous work that directly endangers their health, safety, and moral development make up almost half of all child laborers, about 85 million. Child labor is most common in the agriculture sector, but the ILO report shows that the numbers of child laborers in services and industry are by no means negligible.

The largest absolute number of child laborers is found in Asia and the Pacific region, but sub-Saharan Africa continues to be the region with the 
Table 4.1. Total number of child laborers and number of child laborers doing hazardous work by region, 5-17 age group, 2012

\begin{tabular}{|c|c|c|c|c|}
\hline \multirow[b]{2}{*}{ Region } & \multicolumn{2}{|c|}{ Child laborers } & \multicolumn{2}{|c|}{$\begin{array}{c}\text { Child laborers doing } \\
\text { hazardous work }\end{array}$} \\
\hline & (nillions) & $\%$ & (millions) & $\%$ \\
\hline Asia and the Pacific & 77.7 & 9.3 & 33.9 & 4.1 \\
\hline Latin America and the Caribbean & 12.5 & 8.8 & 9.6 & 6.8 \\
\hline Sub-Saharan Africa & 59.0 & 21.4 & 28.8 & 10.4 \\
\hline Middle East and North Africa & 9.2 & 8.4 & 5.2 & 4.7 \\
\hline
\end{tabular}

Notc: The numbers in the second and fourth columns are the percentages of children as a whole in each region.

Source: International Labour Office, Marking Progress against Child Labour: Global Estimates and Trends 2000-2012 (Geneva: International Labour Office, 2013).

highest proportion of child laborers; one in five children are laborers there. As shown in table 4.1, for the overall 5-17 age group, child laborers number almost 77.7 million in Asia and the Pacific. For the same age group, there are 59 million child laborers in sub-Saharan Africa, 12.5 million in Latin America and the Caribbean, and 9.2 million in the Middle East and North Africa.

Not surprisingly, the incidence of child labor is highest in poorer countries. Twenty-three percent of children in low-income countries are child laborers, compared to 9 percent of children in lower-middle-income countries and 6 percent of children in upper-middle-income countries.

The agricultural sector is by far the most significant employer of child laborers; it employs over 98 million children, 59 percent of the world's child laborers. But the numbers of child laborers in the services and industry sectors are by no means negligible. A total of 54 million are found in the services sector (of which 11.5 million are in domestic work) and 12 million are found in industry.

The ILO report also shows that the number of child laborers has declined somewhat in recent years. There were almost 78 million fewer child laborers at the end of the 2000-2012 period than at the beginning, a reduction of almost one-third. The decrease in the number of female child laborers was particularly pronounced.

The ILO report identifies a number of actions that have driven progress in the reduction of child labor, including the political commitment of governments to reducing child labor, an increasing number of ratifications of ILO conventions, and progressive new public policies in a number of countries. The ILO report concludes that "policy choices and accompanying investments that have been made in two areas appear particularly relevant to the 
decline in child labor over the last 12 years. The first is education. The worldwide Education For All movement has helped marshal major new investments in improving school access and quality, which in turn has provided more families with the opportunity to send their children to school rather than to the workplace and has made it worthwhile for them to do so. It is not chance that the rapid decline in child labor since 2000 coincided with a major increase in school attendance." 8

The second policy area is social protection. While extending access to social security remains a pressing challenge globally, there is clear evidence from multiple countries that investments in social security are associated with lower levels of child labor. This is not coincidental: social security can be essential in mitigating the social and economic vulnerabilities that can lead families to resort to child labor. Many countries also have recently been taking action to establish or revise their lists of what constitutes hazardous work and are including prohibitions of these kinds of work for anyone under 18 years of age as part of enforceable legislation. ${ }^{9}$

\section{THE TECHNOLOGICAL CONTEXT}

Technological change had a major role in workers' early efforts to use unions and other means to improve their employment conditions. It also is clear that across the globe ongoing technological changes will have huge effects on future employment conditions. Yet many people still disagree over how and why technology influenced labor-management relationships and what current technological changes imply for the future of labor relations.

\section{The Historical Debate over the Influence of Technology: Commons versus Marx}

Both Karl Marx and John R. Commons believed that workers were spurred to join unions by technological change, the shift from craft systems of production to wage labor, and the rise of the modern factory system. But they disagreed sharply over exactly why changes in technology and the organization of work had that effect.

For Marx, the critical event in industrialization was the chasm that capitalist methods of production opened between workers and the owners of the means of production. That chasm, according to Marx, would inevitably result in a worsening of working conditions, a profit crisis, and the emergence of a revolutionary class consciousness among workers. Followers of Marx went on to argue that it was the loss of control that workers experienced as a result of shifts in production methods and ownership that led them to form unions. To 
those observers, collective negotiations was (and is) a continuing battle between workers and managers over control of the production process. Harry Braverman built on this argument and claimed that technological change typically leads to a lowering of the skills required in jobs (deskilling) as part of this battle for control. ${ }^{10}$

Commons, on the other hand, observed that the shift in production methods was a product of an expansion of the market brought about by urbanization and new transportation methods. To Commons, as the market expanded and the ownership of production changed, workers encountered a host of competitive menaces such as prison labor and child labor. Workers then turned to unions to protect themselves and improve their standard of living. Commons and his students argued that unions and workers sought income and job security rather than control of the production process. ${ }^{11}$ Thus, although Marx and Commons differed sharply over the interpretation of unions' objectives, both saw the rise of capitalism as the spur to unionization.

To Clark Kerr, John Dunlop, Frederick Harbison, and Charles Myers, it was the process of industrialization and not capitalism per se that brought about the changes in the relationship between workers and employers that led to unionization. ${ }^{12}$ They argued that modern technology produced a need for rules that would govern relations between workers and employers. Collective negotiations were a logical way to formalize and structure the rules required in modern industry. Within this framework, specific technological changes are important in collective negotiations because they result in changes in the relative bargaining power of management or labor. In this regard, the industrialization thesis is closer to the ideas of Commons than to Marx's theories.

\section{The Influence of Microelectronic Technology on Skill Levels}

The recent growth in the use of microelectronic technology has reignited the debate over the effects of technological change. Some believe that this technology can open the way to less hierarchical, higher skilled work and further growth in real incomes. To others, the new technology is being used to wrest control away from the work force and to deskill workers. ${ }^{13}$ These latter observers see little evidence of a shift away from the hierarchical forms of work organization. In fact, these modern proponents of the deskilling thesis argue that much of the concessionary negotiations that has occurred in recent years is the result of the efforts of managers to increase the pace of work and use new technology to weaken workers' bargaining leverage and skills. Proponents of 
the deskilling thesis also predict that new technology will lead to significant employment displacement and unemployment.

A number of behavioral scientists believe that new technologies serve to "unfreeze" existing practices and open up a variety of options for reconfiguring the organization of work, career ladders, compensation criteria, and other aspects of the employment relationship. ${ }^{14}$ According to this view, there is no single effect of technology on skills or workers' power; rather, its effects depend on the choices made by decision makers and the way the new technology is implemented.

\section{Summary}

This chapter examines how the environment influences labor relations in emerging countries. The key issues the chapter addresses are that labor relations are critically shaped by the bargaining power of labor and management and that bargaining power has three key components-total, relative, and political power. The environment shapes all three of these sources of power. This chapter covers the role of the economic, demographic, and technological environments.

Important economic factors include those that operate at the firm level (microeconomic influences) and the state of the labor market and the overall economy (macroeconomic influences). The economic environment is most important through the effects it exerts on the bargaining power of labor and management. Bargaining power is heavily influenced by strike leverage and the extent to which an increase in wages leads to a decline in employment (the wage-employment trade-off).

Major demographic issues include the growth in population and the labor force, the extent of rural-to-urban migration, and the educational attainment of the work force.

Technology influences employment levels and bargaining leverage. In recent years there has been much debate over how technology is affecting the skill levels of workers. On the shop floor, labor relations play an important role in shaping how well new technology is implemented.

How well a labor relations system serves the interests of labor, management, and society often depends on its ability to adapt to changes in the environment. Economic pressures on labor relations systems have grown steadily along with globalization and the expansion in international trade. There are also pressures from the other key environmental dimensions. To help build a better understanding of how labor relations can respond to these environmental challenges, the next chapter examines how collective negotiations function. 


\section{Discussion Questions}

1. Define bargaining power and strike leverage.

2. Several microeconomic factors play a part in the strike leverage of both unions and employers. Briefly describe some of these factors.

3. Describe some policy measures emerging countries have initiated in recent years that have contributed to a reduction in child labor.

4. Contrast the positive and negative effects of technology on workers and working conditions.

\section{Related Web Sites}

Hazardous Child Labour page of the ILO-IPEC Wcb site: http://www.ilo.org/ipec/ facts/WorstFormsofChildLabour/Hazardouschildlabour/lang--en/index.htm

ILO's Global Wage Report: http://www.ilo.org/global/research/global-reports/ global-wage-report/lang--en/index.htm

U.S. Department of Labor, International Child Labor: http://www.dol.gov/dol/ topic/youthlabor/intlchildlabor.htm

\section{Suggested Supplemental Readings}

Blauner, Robert. Alienation and Freedom. Chicago: University of Chicago Press, 1964. Braverman, Harry. Labor and Monopoly Capital. New York: Monthly Review Press, 1984.

Ehrenberg, Ronald G., and Robert S. Smith. Modern Labor Economics. 8th ed. Reading, Mass.: Addison-Wesley, 2003.

International Labour Office. Marking Progress against Child Labour: Global Estimates and Trends 2000-2012. Geneva: International Labour Office, 2013.

Lee, Marlene A., and Mark Mather, "U.S. Labor Force Trends," Population Bulletin 63, no. 2 (June 2008), http://www.prb.org/pdf08/63.2uslabor.pdf.

Todaro, Michael P., and Stephen C. Smith. 2012. Economic Development. Boston: Addison-Wesley.

\section{Notes}

1. John T. Dunlop, Industrial Relations Systems (New York: Holt and Company, 1958).

2. Elasticity of demand refers to the slope of the demand curve for labor. The more inelastic the demand, the more vertical the demand curve and the less responsive the demand for labor is to any change in the price of labor. A perfectly elastic demand curve would be horizontal. Alfred Marshall, Principles of Economics, 8th ed. (New York: Macmillan, 1920), 383-386.

3. Others have pointed out that for a low labor cost ratio to act as a source of power, as Marshall hypothesized, the elasticity of demand for the final product must be greater than the elasticity of substitution of nonlabor inputs in the production process. See Richard B. Freeman, Labor Economics, 2nd ed. (Englewood Cliffs, N.J.: Prentice Hall, 1979), 67-71. 
4. A small bargaining unit can be affected by employers who consider the spillover effects of a settlement negotiated with one small unit on the rest of the firm's work force.

5. Michael P. Todaro and Stephen C. Smith, Economic Development (Boston: AddisonWesley, 2012), 313.

6. The United Nations has created a standardized system called the International Standard Classification of Education for the purpose of comparing different education systems.

7. International Labour Office, Marking Progress against Child Labour: Global Estimates and Trends 2000-2012 (Geneva: International Labour Office, 2013).

8. Ibid., 10.

9. Several reports about and tools for eliminating hazardous child labor are available at the Hazardous Child Labour page of the ILO-IPEC Web site: http://www.ilo.org/ipec/facts/ WorstFormsofChildLabour/Hazardouschildlabour/lang--en/index.htm.

10. Harry Braverman, Labor and Monopoly Capital (New York: Monthly Review Press, 1984).

11. Selig Perlman, A Theory of the Labor Movement (1928; repr., Philadelphia: Porcupine Press, 1979).

12. Clark Kerr, John T. Dunlop, Frederick Harbison, and Charles A. Myers, Industrialism and Industrial Man (Cambridge, Mass.: Harvard University Press, 1960).

13. David F. Noble, Forces of Production (New York: Oxford University Press, 1986); Harley Shaiken, Work Transformed (New York: Holt, Rinehart \& Winston, 1984): Erik Brynjolfssohn and Andrew McAfee, The Second Machine (New York: Norton, 2014).

14. Richard Walton, "Work Innovations in the United States," Harvard Business Review 57 (1979): 88-98; Barry Wilkinson, The Shopfloor Politics of New Technology (London: Heinemann Educational Books, 1983); Stephen Barley, "Technology, Power, and the Social Organization of Work," in Research in the Sociology of Organizations, ed. Samuel B. Bacharach and Nancy DiTomaso (Greenwich, Conn.: JAI Press, 1990). 